\title{
Article
}

\section{Calculation skills in chronic pain management}

\author{
Broadhead, Ruth
}

Available at http://clok.uclan.ac.uk/29284/

Broadhead, Ruth (2019) Calculation skills in chronic pain management. Journal of Prescribing Practice, 1 (7). pp. 326-327. ISSN 2631-8393

It is advisable to refer to the publisher's version if you intend to cite from the work. 10.12968/jprp.2019.1.7.326

For more information about UCLan's research in this area go to http://www.uclan.ac.uk/researchgroups/ and search for < name of research Group>.

For information about Research generally at UCLan please go to http://www.uclan.ac.uk/research/

All outputs in CLoK are protected by Intellectual Property Rights law, including Copyright law. Copyright, IPR and Moral Rights for the works on this site are retained by the individual authors and/or other copyright owners. Terms and conditions for use of this material are defined in the policies page.

\section{CLoK}

Central Lancashire online Knowledge www.clok.uclan.ac.uk

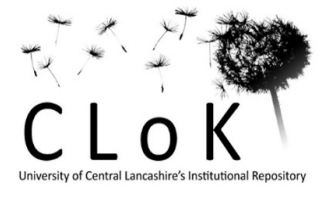




\section{Calculation skills in chronic pain management: answers}

Ruth Broadhead

\section{QUESTION 1}

Ben, aged 52, has type 2 diabetes mellitus and has been commenced on gabapentin capsules for neuropathic pain. The British National Formulary (Joint Formulary Committee, 2019) states that he should be prescribed the following regimen:

Day 1 - gabapentin 300 mg capsule once daily

- Day 2 - gabapentin 300 mg capsules twice daily

Day 3 onwards - gabapentin $300 \mathrm{mg}$ capsules three times a day

a. How many capsules will Ben take in the first 7 days?

- 18 capsules

b. How many capsules will you prescribe for 1 month's supply from the day of commencement (28 days)? - 81 capsules

c. Ben tolerates this dose and you prescribe a further 1-month supply at his review. The pack size of gabapentin $300 \mathrm{mg}$ capsules $=100$ capsules/pack. How many full packs will you request in order to supply Ben with an adequate amount of tablets for 28 days' treatment and how many capsules will remain? - 1 pack (100) to be supplied with 19 capsules left after 28 days

\section{QUESTION 2}

Janet, aged 45, was prescribed buprenorphine transdermal patch 10 micrograms per hour / one patch weekly. After 3 months' use, her pain is not adequately controlled and you decide to increase the strength of the patch by $50 \%$.

a. What is the new strength of the buprenorphine transdermal patch?

- 15 micrograms per hour/one patch weekly

b. If there are 4 patches in a pack, how many packs will she use in 12 months? Assume a calendar month is 28 days.

12 packs c. The cost of one pack of 4 patches is $£ 49.15$. What is the total cost for 6 months' supply?

- 294.90

\section{QUESTION 3}

Morphine sulfate $2 \mathrm{mg} / \mathrm{ml}$ oral solution (Oramorph) is prescribed for lan who is in chronic pain at the end of life. The recommended dose for lan is $10 \mathrm{mg}$ every 4 hours.

a. How many $\mathrm{ml}$ of morphine sulfate should lan take per dose?

$5 \mathrm{ml}$

b. How many $\mathrm{ml}$ of morphine sulfate will lan require in 24 hours?

$30 \mathrm{ml}$

c. Ian is supplied with a bottle containing $300 \mathrm{ml}$. Assuming lan takes the full-recommended dose; calculate how many days his oral solution will last. 10 days

\section{QUESTION 4}

Charlotte has chronic back pain due to previous orthopaedic surgery. Tramadol hydrochloride (modified-release) was prescribed and she has been taking one $200 \mathrm{mg}$ tablet every 12 hours for 6 months. Charlotte has decided she wants to reduce this medication. As a prescriber, you agree to reduce the strength by $25 \%$ every 2 weeks.

a. What is the strength of tramadol that you will prescribe first?

- $150 \mathrm{mg}$ tablet every 12 hours

b. How many tablets will you prescribe for the first

2 weeks' treatment?

- 28 tablets

c. After 6 weeks, what strength of tramadol will Charlotte be prescribed?

$50 \mathrm{mg}$ tablets every 12 hours 